Małgorzata Gorczyńska

Instytut Filologii Polskiej, Uniwersytet Wrocławski

\title{
W Zatoce Syreny: Lawinia i Strefa komfortu Tomasza Różyckiego
}

Wiersz Tomasza Różyckiego Strefa komfortu z najnowszego tomu Kapitan X (2020) kończy się obrazem łączącym dwa typowe rekwizyty klasycznego locus amoenus: trawę i drzewo. Drzewo, jak wynika z poprzedzających wersów, rośnie w miejskim parku; jest popołudnie lub wczesny wieczór, jeszcze świeci słońce. Kilka linijek wyżej mowa była o jachcie „kołyszącym się u wybrzeża Capri”, co sugeruje, że park znajduje się gdzieś w rejonie Golfo di Napoli. Pasuje tu np. Parco Virgiliano na wzgórzu Posillipo w Neapolu, z rozległym widokiem na zatokę - w pobliżu są nie tylko eleganckie wille, lecz także penthouse'y, o których wspomniano w wierszu; z pewnością w okolicy znajdzie się też drogi samochód, za którego kierownicą siedzi kobieta z torebką od Gucciego (kolejny włoski trop w utworze). Również nazwa parku jest stosowna, ewokuje odpoczynek w cieniu rozłożystego buka z incipitu Eklogi I Wergiliusza'.

A jednak obraz, o którym mowa, nie jest idylliczny. Wiersz rozpoczyna się od słów: „Dobrze się placze w luksusowym aucie”-

1 Ernst Robert Curtius [2009: 198] wskazał Eklogę I jako jedno z głównych źródeł „motywu bukolicznego spoczynku” (na trawie, w cieniu drzewa) obecnego w całej literaturze europejskiej. 
samochód o dźwiękoszczelnych szybach, penthouse na wysokim piętrze budynku czy jacht w marinie na Capri stanowią „strefę komfortu" ludzi bogatych, lecz nieszczęśliwych (to także topos, żywotny we frazesach o tym wszystkim, czego nie da się kupić za pieniądze). W każdym z tych miejsc można wygodnie i dyskretnie popełnić samobójstwo, komfort zaś polega na higienicznej izolacji od tego, co dzieje się gdzieś obok:

kiedy tamci jeszcze śpią w pustym parku, czekając do zmierzchu, żeby znaleźć coś dziś do zjedzenia na śmietnikach miasta. Na mokrej trawie, gdzie drzewo wyrasta w kierunku nieba niby prosząca dłoń.

[Różycki 2020: 18]

Przypuszczam, że obraz ten nie skojarzyłby mi się z sielankową topiką klasycznej poezji ani nie przywiódłby mi na myśl właśnie Parco Virgiliano (w którym, prawdę mówiąc, nigdy nie byłam i nie wiem, czy naprawdę koczują tam ludzie), gdyby nie pewien utwór Różyckiego z wcześniejszego tomu Litery (2016). Wiersz zatytułowany Lawinia transponuje we współczesną czasoprzestrzeń garść motywów z początku Księgi viı Eneidy Wergiliusza - przybycie Eneasza do Lacjum i towarzyszące temu zdarzenia, które stanowiły preludium wojny o prawo do poślubienia latyńskiej królewny Lawinii. W ramach transpozycji trojańscy tułacze stali się uchodźcami próbującymi dotrzeć drogą morską do Europy, natomiast tytułowa bohaterka przybrała zwielokrotnioną postać miejscowych (włoskich) dziewcząt:

Łódź uchodźców przewraca wreszcie piąta fala w mętnej dzisiaj Zatoce Imienia Syreny, i morze, które lubi dzieci, zaraz zabiera je w długą odyseję, by w końcu położyć na piasku Avalon, Itaki, Lampedusy. Boginie i bogowie tym razem dyskretnie 
obserwują to sprzed ekranów, podzieleni.

Ci kibicują Grekom, ci Trojanom.

Jednak gdy któreś znudzone przełączy kanał, szala się przechyla i zdarza się, że morze wróci kogoś do życia na żwirowej plaży. Teraz jest za drutami, przy wę́́le autostrad

gryzie swe suche placki, czeka na decyzję dotyczącą azylu na ziemi Latynów, których córki o ognistych włosach, jak mówią, w prostej linii pochodzą od Fauna.

[Różycki 2016: 27]

Pod względem formalnym stylizowana Lawinia nie przypomina krótszej, prostszej, bardziej powściągliwej poetycko Strefy komfortu. Tematycznie jednak oba utwory są sobie bliskie, a późniejszy można nawet uznać za kontynuację Lawinii - finalny obraz daje wgląd w życie przybyszów po uzyskaniu azylu². Nie jest też wykluczone, że pisząc Strefę komfortu, Różycki miał w pamięci ten sam fragment Księgi viI Eneidy (wersy 141-147 w przekładzie Zygmunta Kubiaka), do którego odwołał się w Lawinii zaledwie kilka lat wcześniej³. Fragment ów przedstawia pierwszy odpoczynek trojańskich tułaczy na nowej ziemi:

W cieniu gałęzi wysokiego drzewa

Kładą się, aby odpocząć, Eneasz,

Pierwsi przywódcy, piękny Julus. Ucztę

Zjedzą na trawie. Pod połcie mięsiwa

2 „Tamci” śpiący w parku mogliby oczywiście być miejscowymi kloszardami. Zdaję sobie sprawę, że widząc w nich uchodźców, projektuję na niedookreśloną w tym miejscu Strefę komfortu sensy wcześniejszego utworu Tomasza Różyckiego, a także (może nawet przede wszystkim) swoje prywatne wspomnienie z pobytu w Neapolu w 2018 roku: widok młodych, bezdomnych Afrykańczyków, przetrząsających późnym wieczorem stosy śmieci przy bazarze na Via Nolana. Pierwodruk Strefy komfortu ukazał się w internetowym magazynie „Dwutygodnik" w roku 2018. 
Wsuwają placki z orkiszu (sam Jowisz

Natchnął ich), wieńcząc te zbożowe płaty

Leśnym owocem $[. .$.$] .$

[Wergiliusz 1998: 247] $]^{4}$

Zbieżności można zauważyć już na poziomie wersyfikacji (jeśli odniesieniem będzie jedenastozgłoskowa Eneida w thumaczeniu Kubiaka, co wydaje mi się uzasadnione), ale przede wszystkim dotyczą one doboru i układu motywów. W narracji Wergiliusza obecne są wszystkie kluczowe elementy finalnego obrazu Strefy komfortu: nie tylko drzewo i trawa, lecz także głodni ludzie leżący na ziemi. Inaczej jednak niż w Eneidzie, w wierszu Różyckiego miejsce pod drzewem nie może być uznane za przyjemne. Trawa jest mokra, zapewne po deszczu, może to chłodna pora roku; gałęzie drzewa przypominają wyciągniętą w górę dłoń żebraka (z nieba nie patrzy żadne przychylne bóstwo), a leżący ludzie nie mają co jeść. Negatywna wersja locus amoenus - niezależnie od tego, czy topos został zaczerpnięty od Wergiliusza czy z anonimowych zasobów kultury - ma wartość retoryczną, kontrastuje „strefy komfortu” bogatych rezydentów i „tamtych” śpiących w parku oraz uwypukla drastyczną nieprzystawalność ich sytuacji życiowych (po jednej stronie komfort samobójstwa, po drugiej dyskomfort walki o przetrwanie). Retoryczna organizacja Strefy komfortu jest zresztą czymś, czego nie sposób przeoczyć. Dotyczy to w szczególności pierwszej z dwóch strof, skomponowanej gradacyjnie (tabletki w samochodzie, skok z okna penthouse'u, przedawkowanie narkotyków na jachcie - to coraz lepsze, bardziej komfortowe metody samobójstwa). Łatwo wyczuwalny jest też sarkastyczny ton i oskarżycielska wymowa utworu. Nawet ostatnie, najbardziej liryczne wersy zostają zabarwione ironią, kiedy czyta się je w kontekście sceny z Eneidy lub podobnych sielankowych przedstawień.

A jak cytowany fragment $\mathrm{z}$ Wergiliusza funkcjonuje w Lawinii? Oryginalne locus amoenus zastąpione zostało miejscem „za drutami, przy węźle autostrad”, a z uczty pod drzewem pozostał tylko jeden księgi i łaciński numer wersu w przekładzie Zygmunta Kubiaka [Wergiliusz 1998]. 
składnik: „suche placki”, które zresztą wyglądają tu naturalnie, po prostu jak chleb ubogich (z pewnym znamieniem egzotyzmu: „swe”). Aluzyjność jest więc zatarta i można by ją przeoczyć, gdyby nie wyrazista instrukcja intertekstualna w tytule. W zestawieniu z Eneidą widać, że motyw został przekształcony w swój negatyw, lecz funkcja takiego odwrócenia pozostaje niejasna. Dotyczy to też pozostałych transformacji (zatopiona łódź zamiast pomyślnego lądowania, boginie i bogowie powstrzymujący się od interwencji etc.). Przewijające się przez narrację Lawinii określenia: „dzisiaj”, „tym razem”, „teraz” podkreślają kontrast między heroiczną, triumfalną historią Eneasza a ponurym losem współczesnego uchodźcy. Sprowadzenie sensu wiersza do takiej antytezy wydaje się jednak zbyt prostoduszne, nie bierze bowiem pod uwagę tych semantycznych i stylistycznych składników wiersza, które wyłamują się $\mathrm{z}$ przeciwstawienia. Obie historie są różne, a zarazem zastanawiająco podobne: mityczno-literacka prześwituje spod współczesnej. Podobnie jest ze stylem, który ulega co prawda pewnej degradacji wskutek transpozycji tematu, ale jednocześnie zachowuje rysy pokrewne stylowi Wergiliusza.

Lawinia nie oferuje więc takiej prostej, czarno-białej wizji świata, jak Strefa komfortu. Wykładnikiem złożoności wcześniejszego utworu jest także niejednoznaczność referencji czasoprzestrzennych. O ile odwołania do współczesnych realiów w Strefie komfortu są spójne i konsekwentne (nawet jeśli w aspekcie spacjalnym wiersz pozostawia sporo niedomówień; Neapol i Parco Virgiliano to tylko moje niezobowiązujące domysły), o tyle Lawinia buduje swój chronotop z elementów niejednorodnych, odsyłających nie tylko do rzeczywistości, lecz także do świata fikcji. Technicznie rzecz biorąc, jest to utwór heterodiegetyczny (z przybliżającym przeniesieniem czasowym i trywializacją społeczną) transpozycji nie można jednak uznać za pełną. Sceny przedstawione w wierszu rozgrywają się w teraźniejszości, współczesne rekwizyty

5 Posługuję się terminologią, którą Gérard Genette po części wprowadził, a po części tylko spopularyzował w rozprawie Palimpsesty. Literatura drugiego stopnia. Transformacje heterodiegetyczne są związane ze zmianą ról społecznych bohaterów, co pociąga za sobą zmianę „miejsca, epoki i środowiska” [Genette 2014: 323 (o przybliżeniu i trywializacji społecznej zob. s. 330-331)]. 
świadczą o tym, że czas teraźniejszy narracji to nie praesens historicum, a mimo to kraj, do którego zmierzają uchodźcy, nosi wciąż nazwę „ziemi Latynów”; nadal w mocy pozostaje boska genealogia jego mieszkańców. W konstrukcji przestrzeni pojawia się ponadto stałe napięcie między „tutaj, w tym samym miejscu co wtedy”, a „niezupełnie tutaj”, połączone z oscylacją między precyzją umiejscowienia a lokalizacyjnym rozszerzeniem czy wręcz rozmyciem. To napięcie i oscylacja uruchamiane są już przez tytuł. Użyta w nim nazwa własna nie jest wprawdzie toponimem, ale ma konotacje geograficzne: Lavinia litora, „brzegi lawińskie”, wspomniane już w pierwszych heksametrach Eneidy jako kres tułaczki Trojan, to okolice ujścia Tybru do Morza Tyrreńskiego. Na południe od koryta rzeki znajdował się w czasach antycznych port Lawinium, według rzymskich legend założony przez Eneasza, a nazwany na cześć córki króla Latynusa, którą trojański bohater pojął za żonę w przybranej ojczyźnie i z którą spłodził protoplastę starożytnych Rzymian (oraz współczesnych Włochów). Kiedy w pierwszym wersie Lawinii mowa jest o „mętnej dzisiaj Zatoce Imienia Syreny”, to jest to aluzja do spokojnego morza, jakie powitało Trojan u „brzegów lawińskich”, toponim sugeruje jednak, że współczesne Lavinia litora nie znajdują się już na skraju Lacjum (historycznego czy dzisiejszego). Fikcyjna nazwa wskazuje najpewniej na południowe wybrzeże Lampedusy (przez skojarzenie z Syrena Giuseppe Tomasiego di Lampedusy; wyspa Lampedusa przywołana jest wprost kilka wersów dalej), stanowiące Porta d’Europa ${ }^{6}$ dla przybyszów z Libii, Syrii, Tunezji czy Erytrei. W tle pojawia się wszakże owa zatoczka powyżej Punta Izzo na Sycylii, gdzie Rosario La Ciura poznał syrenę Ligheę. Pozostałe toponimy, legendarno-celtycki „Avalon” oraz literacko-grecka „Itaka”, jeszcze bardziej rozszerzają przestrzeń Lawinii, i to

6 Nawiązuję do tytułu instalacji Mimmo Paladino Porta di Lampedusa, Porta d'Europa, która od 2008 roku stoi na najbardziej wysuniętym na południe cyplu Lampedusy.

7 Sycylia ma tu także inne uzasadnienie: to właśnie tam transportowani są ludzie, którym udaje się dotrzeć do niewielkiej Lampedusy. Warto przypomnieć, że zbiorczy ośrodek dla ubiegających się o azyl w Mineo na Sycylii, będący największym tego typu centrum w Europie, został zamknięty z polecenia wicepremiera Włoch Matteo Salviniego w 2019 roku. Nadal jednak działają - bardzo przepełnione - mniejsze obozy. 
nie tylko w sensie ściśle geograficznym - to terytorium, a zarazem pewne uniwersum kulturowe. Natomiast użyte w kontekście starań o azyl określenie „na ziemi Latynów” znów tę przestrzeń zawęża do granic współczesnego państwa włoskiego. Wystarczy wszakże uświadomić sobie anachronizm tej nazwy oraz jej literackie źródło, a już wracają Lacjum, Tyber, Lavinia litora.

Wszystko to powoduje, że tak trudno jest określić tryb, w jakim Lawinia ma być czytana. Utwór może sprawiać wrażenie interwencyjnej publicystyki: uchodźcy giną lub tkwią beznadziejnie we włoskich ośrodkach, nie wystarczy o tym tylko dyskutować, trzeba coś zrobić. Można też domniemywać, że wiersz ironicznie przedstawia ideę wielokulturowości opartą na zmitologizowanych, idyllicznych wizjach bezkonfliktowej koegzystencji ludzi stąd i przybyszów (małżeństwo Eneasza z Lawinią jako prapoczątek Rzymu, Europy, Zachodu); wydaje się, że ironia ma skłonić do tego, by skonfrontować mit z rzeczywistością. Można jednak czytać wiersz na odwrót: Eneida dostarcza pozytywnego wzorca relacji Europejczyków z uchodźcami, a to, że rzeczywiste spotkanie przebiega według innego scenariusza, jest moralnym skandalem. Można wreszcie spojrzeć na utwór jeszcze szerzej i zobaczyć w nim stylizowaną przypowieść o odrzuceniu Obcego. Tak interpretuje Lawinię Marek Stanisz [2019: 149]:

[...] sztafaż Wergiliańskiej opowieści o Eneaszu nie tylko uwzniośla losy współczesnych imigrantów z Afryki, ale przede wszystkim nadaje ich dramatycznej tułaczce (i naszym na nią reakcjom) uniwersalny wymiar wiecznie powtarzającej się, ciągle na nowo odgrywanej historii osamotnienia i obojętności.

Wszystkie te odczytania są jakoś uprawnione, niemniej wydają się niepełne. Żadne z nich nie wyjaśnia satysfakcjonująco roli intertekstualnych odniesień w wierszu Różyckiego (nazwać je „sztafażem" to zdecydowanie za mało). Nadal nie wiadomo, czy Eneida stanowi pozytywny wzorzec, czy przedmiot krytyki; czy język i światopogląd eposu są odrzucane, czy przyjmowane za własne. Żadne nie poświęca też dostatecznej uwagi ani retoryce Lawinii, ani jej poetyckości. Moja propozycja interpretacyjna będzie więc 
próbą syntezy wszystkich tych rozpoznań - a jednocześnie wyjściem poza nie. Chciałabym pokazać osobliwą dynamikę utworu, polegającą na ciągłej cyrkulacji tonów ironicznych i czułych, zretoryzowanego dyskursu i poetyckiego wglądu. W dynamice tej, jak się okaże, kluczową rolę odgrywają epickie hipoteksty, na przemian przysłaniane i wydobywane na światło. W tle zaś pojawia się włoski krajobraz - literacki i mityczny, a zarazem najzupełniej rzeczywisty.

Zacznę od ogólnego spostrzeżenia, że Lawinia zawiera nie jedną, lecz dwie kontrapunktowe opowieści o uchodźcach zmierzających do „brzegów lawińskich”. Każda z nich przyjmuje inny punkt widzenia, inną odległość od swoich bohaterów, każda też używa innego głosu, i to właśnie jest źródłem semantycznego oraz stylistycznego rozedrgania, które próbowałam wstępnie opisać. Przekładając teraz synchronię dzieła na diachronię procesu analityczno-interpretacyjnego, proponuję lekturę rozłożoną na dwa etapy. Najpierw przeczytam Lawinię jako persyflaż, krytyczne naśladowanie głosu dobrze znanego, a jednak postrzeganego jako cudzy. Następnie zaś pokażę, jak ten sam utwór pozwala, by wybrzmiały w nim głosy inne, wprawdzie nadal nietożsame z głosem autorskim, ale dużo mu bliższe niż tamten pierwszy.

Na trop persyflażu naprowadza słowo „wreszcie” w pierwszym wersie Lawinii: „Łódź uchodźców przewraca wreszcie piąta fala”. Jest ono sygnałem narracyjnego wejścia in medias res, ale słychać w nim też jakieś wykrzyknikowe „no, nareszcie!”, z wyrazem ulgi po napiętym oczekiwaniu lub z satysfakcją, że odgadło się, co zaraz nastąpi. Czyje to emocje? Narracja jest konsekwentnie trzecioosobowa, gramatycznym śladem mówiącego podmiotu są tylko deiktyczne określenia czasu: „dzisiaj”, „tym razem”, „teraz” oraz praesens czasowników. Byłaby to zatem albo relacja na żywo, albo komentarz do wydarzeń przedstawianych jako aktualne. Wzmianki o ekranach i przełączaniu kanałów pozwalają się domyślić, że chodzi o przekaz telewizyjny. Przedmiotem ironicznej imitacji w Lawinii jest więc język telewizji jako wpływowego mass medium; oczywiście chodzi przede wszystkim o najbardziej prymitywne odmiany tego języka. W centrum uwagi jest zwłaszcza kwestia przemożnego wpływu telewizji (a zapewne też innych popularnych mediów) na świadomość masowej publiczności. Medialny dyskurs o uchodźcach kształtuje 
perspektywę wyposażonych w piloty „bogiń i bogów”, niezależnie od tego, komu „kibicują”: czy ronią łzy nad losem „tych biednych ludzi”, czy też domagają się twardej polityki wobec „nielegalnych imigrantów". Punkt widzenia znajduje się bowiem w obiektywie kamery. Sposób prowadzenia opowieści precyzyjnie steruje odbiorem, sprawiając np. że po odpowiednio długiej sekwencji obrazów łodzi rzucanej przez fale widz wypowiada słowo „wreszcie” na widok katastrofy.

Opowieść o uchodźcach w Lawinii przypomina materiał reportażowy z telewizyjnych wiadomości. Składa się z serii dynamicznie zmontowanych obrazów-kadrów: zbliżenie przepełnionej łodzi; przewracająca ją fala; nieco dłuższe ujęcia ciał dzieci dryfujących po morzu i wyrzuconych na przybrzeżny piasek jakiejś wyspy; przebitka z innej plaży, żwirowej, na której znajduje się ktoś (postać zamazana, chyba mężczyzna), komu udało się ujść z życiem; widok przez druty obozu przy krzyżujących się autostradach, gdzie (ten sam?) człowiek ocalały z przewróconej łodzi gryzie jakiś suchy placek; na koniec migawka z grupą dziewcząt pozujących pod marmurowym posągiem Fauna. Przedstawienie jest skrótowe i schematyczne, sekwencja zdarzeń przewidywalna, bohaterowie pozbawieni indywidualności, komentarz z offu nie oferuje żadnych pogłębionych wyjaśnień. Również reakcje widzów przebiegają według z góry określonego wzorca: najpierw wzburzenie, potem nieunikniony spadek uwagi.

O prawdziwym charakterze tej z pozoru czysto sprawozdawczej i tylko z konieczności pobieżnej narracji pewne pojęcie daje to, jak funkcjonują w niej kulturowo obciążone nazwy własne. Kontekst reportażu z jego powierzchownością, z językowymi i myślowymi kliszami („lubi dzieci”, „kibicują”, „za drutami” etc.) sprawia, że historyczny i estetyczny bagaż tych nazw ulega zatarciu, a one same zostają strywializowane. Efektem jest „Zatoka Imienia Syreny”, wyglądająca na produkt marketingu turystycznego, „Avalon”, „Itaka” i „Lampedusa” z wakacyjnych prospektów, „Grecy” oraz „Trojanie” jak określenia drużyn futbolowych, a do tego „ziemia Latynów” niby pretensjonalna dziennikarska peryfraza. To beztroskie przemieszanie dostojnej tradycji z niską potocznością jest kwintesencją stylu i światopoglądu telewizyjnego reportażu. 
Przy odrobinę bliższym spojrzeniu telewizyjny dyskurs ujawnia swoje intertekstualne podszycie, ale sensy, które mogłyby się wyłonić z literackich odwołań, zostają od razu wplątane w dziennikarską retorykę, w grę na emocjach. W trosce o dobre samopoczucie widzów sterujące ich spojrzeniem oko reporterskiej kamery konsekwentnie przyjmuje perspektywę zewnętrzną względem uchodźców: z wybrzeża zatoki, z głębi żwirowej plaży, od drugiej strony obozowych drutów - epicki dystans zapewnia dogodną pozycję boskich obserwatorów. Użycie mitologiczno-literackiego filtra pozwala natomiast złagodzić dyskomfort oglądania nieprzyjemnych obrazów. Relacja o śmierci dzieci brzmi jak homeryckie bajanie: „[... ] i morze, które lubi dzieci, zaraz zabiera / je w długą odyseję, by w końcu położyć / na piasku Avalon, Itaki, Lampedusy”. Konwencje mitu i fikcji literackiej pozwalają przyjąć postawę udawanej naiwności, dzięki której można całą moc sprawczą (i moralną odpowiedzialność) przypisać siłom natury: to fala przewraca łódź, to morze zabiera dzieci i to ono niekiedy „wróci kogoś do życia na żwirowej plaży”. Można też pomijać niewygodne niuanse i zadowalać się powierzchownymi podobieństwami. Eneasz i jego towarzysze to obcy, tułacze, uchodźcy, całkiem jak ci dzisiejsi. Określenie „łódź uchodźców” sugeruje, że do lądu zbliża się drużyna młodych, silnych mężczyzn, jak u Wergiliusza. Miejsce „za drutami, przy węźle autostrad” jest obozem - Trojanie też w takim zamieszkali:

\section{[...] A Eneasz}

Wyznacza płytkim rowem linię murów,

Trudzi się nad tą ziemią, opasuje

Pierwsze osiedle na nowym wybrzeżu,

Na wzór obozu, szańcem i blankami.

[E VII 243-247]

Wynajdywanie kojących analogii, np. na podstawie homonimii, dzieli bardzo cienka granica od manipulacji oraz instrumentalnego wykorzystania hipotekstów - i tu telewizyjny dyskurs ujawnia swe ciemne strony. Najdalej posunięte przeinaczenie dokonuje się w finale reportażowej narracji i obejmuje wiele różnych fragmentów Eneidy. Pierwszym, jaki należałoby uwzględnić, jest cytowany tu już 
częściowo passus o uczcie, podczas której wygłodniali mężczyźni nie zdołali nasycić się „połciami mięsiwa” oraz „leśnym owocem”, więc sięgnęli po placki z orkiszu, na których zostało rozłożone jedzenie:

\section{[...] Gdy resztę spożyli,}

Ubóstwo jadła pchnęło ich do tego,

By wbili zęby w cienkie placki: ręką

I zuchwałymi zębami gwałcili

Brzemienne losem ciasto, nie szczędzili

Wielkich kwadratów. „Co się dzieje! Nawet

Stoły zjadamy!” - śmiejąc się, zakrzyknął

Julus i więcej nic nie rzekł. Ten okrzyk

Był pierwszym znakiem końca ich udręczeń.

[E VII 147-155]

Sformulowanie „brzemienne losem ciasto” nawiązuje do przepowiedni, że kiedy głód zmusi trojańskich tułaczy do gryzienia stołów, to „mogą po trudach spodziewać się domu” [E VII 167]. „Suche placki” współczesnych uchodźców zyskują w ten sposób znaczenie zapowiedzi. Kolejny hipotekst, który pojawia się w horyzoncie reportażowego dyskursu, to końcowe zdania z przemowy posłów Eneasza do Latynusa:

\section{$\mathrm{Z}$ tego potopu ocaleni, wiele}

Mórz przepłynąwszy rozległych, prosimy

O trochę miejsca dla bogów ojczystych,

O brzeg bezpieczny, o to, co jest wszystkim

Dostępne: wodę i powietrze. Żadnej

Nie przyniesiemy królestwu niesławy.

[E VII 315-320]

W relacji reportażowej poselstwu Eneasza odpowiada wniosek o „azyl na ziemi Latynów”. Gdzieś w tle pojawia się sugestia, że współcześni uchodźcy udzielają podobnych zapewnień jak Trojanie i zgłaszają podobne postulaty, tyle tylko, że nic nie wiadomo o tym, by były one legitymizowane zrządzeniem sił wyższych. Ponadto zaraz po stwierdzeniu, że uchodźca czeka na decyzję w sprawie 
legalizacji pobytu (historia Eneasza każe przypuszczać, że będzie to decyzja pozytywna), dość nieoczekiwanie wspomniane zostają „córki o ognistych włosach”. Sformulowanie to jest aluzją do sceny z Eneidy, w której podczas zapalania na ołtarzu świętego płomienia włosy Lawinii zajęły się ogniem, co świadkowie odczytali jako przepowiednię przyszłej chwały córki Latynusa, a także wojny, która wybuchnie z powodu dziewczyny. Kiedy Latynus zasięgnął w tej sprawie rady swojego „wieszczego rodzica”, usłyszał od Fauna:

\section{„O mój synu!}

Nie dla twej córki małżeństwo latyńskie!

Komnacie ślubu, która już gotowa,

Nie ufaj! Przyjdą, by stać się zięciami,

Obcy mężowie: ich krew imię nasze

Aż do gwiazd wzniesie $[\ldots]$ ”.

[E VII 125-130]

Nieuważna lektura tego proroctwa wydobywa z niego niepokojące treści: „Nie dla twej córki małżeństwo [...] Nie ufaj! Przyjdą, by $[\ldots]$ Obcy mężowie $[\ldots]$ krew $[\ldots]$... Z kolei w samej narracji reportażowej nagłe przejście od „suchych placków” do „córek o ognistych włosach” przemyca podejrzenie, że czekający na azyl mężczyzna kieruje swój głód ku ognistowłosym Lawiniom. Nie zostaje to powiedziane wprost, insynuacja opiera się na naddanym sensie odpowiednio zmontowanych obrazów: kadr z obozu, zbliżenie ust mężczyzny gryzącego podpłomyk, a zaraz potem migawkowe ujęcie dziewcząt zalotnie poprawiających włosy. W sformułowaniu „gryzie swe suche placki” pobrzmiewa ponadto echo Wergiliuszowego „ręką / i zuchwałymi zębami gwałcili”. W enigmatycznej puencie reportażu kryje się ostrzeżenie, że przybysze przemocą sięgną po niewinne latyńskie dziewczęta (w liczbie mnogiej, bo będzie to proceder powszechny, wszak „to już taka kultura”, „oni tak traktują swoje kobiety”). Końcowy ekskurs genealogiczny nie jest tylko ozdobnikiem - złowrogo rezonuje w nim ideologia czystości krwi.

Nie ulega wątpliwości, że sens globalny Lawinii wynika z ironicznego stosunku do takiej konsolacyjno-insynuacyjnej narracji 
o uchodźcach oraz do dokonujących się w ramach tej narracji zawłaszczeń kanonicznych tekstów kultury europejskiej (takich jak Eneida, Odyseja czy Syrena) - do tego, jak owe teksty są trywializowane, sprowadzane do pustych znaków, przeinaczane, nadużywane w niejasnych (czy może aż nadto jasnych) celach. Ironia odróżnia oryginalne hipoteksty od ich zbanalizowanych wcieleń; prawdziwą Eneidę od jej spotworzonej telewizyjnej imitacji przez małe „e”. Co oczywiste, persyflaż pełni funkcję demaskatorską, pomaga zrekonstruować obraz świata implikowany przez medialny dyskurs, odsłania skrywane kategoryzacje i związaną z nimi aksjologię, ujawnia retoryczne chwyty, wreszcie odbija jak w lustrze pozy przyjmowane przez odbiorców mass mediów.

Jeśli chodzi o tę ostatnią sprawę, to można się zastanawiać, czy ironia jest w tym wypadku także autoironią. Przypominam sformułowanie interpretatora Lawinii o „naszych [obojętnych - M.G.] reakcjach" na los uchodźców. Czy perspektywa biernych widzów jest perspektywą „naszą” w mocnym sensie tego słowa, tzn. również perspektywą Różyckiego i jego czytelników? Szerokie spektrum poglądów „bogiń i bogów” („ci kibicują Grekom, ci Trojanom”) wydaje się wspierać odpowiedź twierdzącą: tak, ty i ja też się tu mieścimy. Jest to jednak ujęcie nadmiernie generalizujące, podejrzanie bliskie komunałowi odnotowanemu przez Gustave’a Flauberta: „Epoka - zawsze nasza”, oraz pokrewnym banałom o „naszej kulturze”, „naszych dzieciach”, „naszych potrzebach” etc. ${ }^{8}$ Warto także zwrócić uwagę na szantaż emocjonalny związany z wielkim kwantyfikatorem zaimka w pierwszej osobie liczby mnogiej. Z tego „my”, „nasze” nie sposób się wyplątać, a otwarta odmowa uczestnictwa w takiej wspólnocie spotka się z zarzutami umywania rąk, pięknoduchostwa, moralnego zadufania.

Lawinia pozostawia tę kwestię w niejakim zawieszeniu: „boginie i bogowie” to nie „my”, ale też niezupełnie „oni”. W ogóle trzeba zauważyć, że Różycki nie umieścił w wierszu właściwie żadnych w pełni oczywistych znaków dystansu. Nawet przekroczenie ramy

8 Sam Różycki [2013: 53] jest wyczulony na tę kwestię, o czym świadczy autorefleksyjna uwaga w Tomi: „[... ] dlaczego mówię w liczbie mnogiej - czy to polska choroba?". 
diegetycznej w zwierciadlanym obrazie „bogiń i bogów”, kiedy reportaż o uchodźcach portretuje własnych odbiorców ${ }^{9}$, nie jest wyrazistym złamaniem naśladowanej konwencji, obejmującej wszak uliczne ankiety, sondaże oglądalności, opinie telewidzów-internautów wyświetlane na paskach u dołu ekranu. Naturalnie zawsze można przyjąć, że dystans jest domyślny - wiadomo, jakie jest stanowisko autora w tej sprawie ${ }^{10}$. Gdyby jednak chcieć wskazać miejsce, w którym można nieco wyraźniej usłyszeć głos inny niż ten przedrzeźniany w persyflażu, to byłoby nim zakończenie wiersza, gdzie dokonuje się drobna, ale wyczuwalna zmiana stylistyczna. W efekcie końcowy fragment wysuwa się z naładowanej potocyzmami reporterskiej narracji. Ta ostatnia wprawdzie od początku miała kontakt z językiem klasycznej epopei, ale zajmowała w tym układzie pozycję dominującą. Tu natomiast język eposu uzyskuje względną swobodę. Owszem, służy telewizyjno-reportażowej retoryce, ale brzmi po swojemu:

\section{[...] na ziemi Latynów,}

których córki o ognistych włosach, jak mówią, w prostej linii pochodzą od Fauna.

Pięknie skrojona fraza spuentowana jest wersem nieco krótszym, na podobieństwo Wergiliańskich niedokończonych hemistychów; wtrącenie „jak mówią” jawnie naśladuje sposób mówienia narratora Eneidy („Faunus - wiemy z dawnej wieści - / Był jego ojcem" [E vil 6o]). Całość brzmi lekko, zwłaszcza po wcześniejszych chropowatościach („na żwirowej plaży $[\ldots]$ za drutami $[\ldots]$ autostrad $[\ldots]$ gryzie $[\ldots]$ decyzję $[\ldots]$ azylu"), i można by o niej

9 Taką „zwierciadlaną projekcję" Genette [2014: 322] nazywa „efektem wideo” i wyjaśnia, że polega ona na „tożsamości świata diegetycznego i ekstradiegetycznego”. W Lawinii komplikację wprowadza to, że telewidzowie jako „boginie i bogowie" są częścią tego samego świata (diegezy) co uchodźcy - tak samo jak w starożytnych eposach, w których bóstwa stanowily po prostu specjalną kategorię bohaterów.

To proste, jest ono dokładnie takie jak „nasze”, kimkolwiek tym razem jesteśmy „my”: osobami o pewnej wrażliwości (lubi się ją nazywać lewicową, co jednak niewiele wyjaśnia), ludźmi na odpowiednim poziomie, obdarzonymi zmysłem krytycznym, należącymi do takich, a nie innych kręgów etc. 
powiedzieć to, co napisano o samym eposie Wergiliusza: „[...] dźwięk, wizja, sens stanowią $[\ldots]$ jedność, która nasyca frazy poematu taką magią, że przemawiają one nawet wtedy, gdy są przerwane, gdy milkną" [Kubiak 1998: 34]. Co istotne, to właśnie tutaj po raz pierwszy, i tylko na moment, jak wybuchający nagle płomień, pojawia się postać tytułowej Lawinii. Jest to miejsce, w którym mroczna retoryka spotyka się ze światłem poezji.

Od tego miejsca - a ściślej: od ostatniego słowa utworu, czyli od mityczno-poetyckiego Fauna, którego z tytułową Lawinią łączy „prosta linia”, oś biegnącą przez cały wiersz - trzeba czytać Lawinię na nowo, tym razem wstecz, niejako pod prąd ironii. Lektura ta ujawni kolejne poziomy wielowarstwowego palimpsestu, jakim jest ten wiersz, a ponadto inaczej naświetli hipotekstowe fragmenty, które w czytaniu progresywnym rozumiane były jako zmanipulowane, przykrojone do potrzeb reportażowej narracji. Fragmenty te będą teraz mogły w pełni wybrzmieć, przemówić od siebie. W tym trybie lektury pożądana jest więc uważna, wyczulona na subtelności rewizja źródeł. Punktem wyjścia powinna być scena z płonącą Lawinią w Eneidzie:

A jeszcze stało się tak: Gdy ołtarze Król poświęconą pochodnią zapalał, A przy nim była dziewicza Lawinia, Córka, ujrzano nagle, z jakąż zgrozą, Że długie włosy zajęly się ogniem.

Strój głowy z trzaskiem gorzeje, warkocze

Królewny płoną i perłowy diadem.

W dym się spowiła gęsty, w żóltą łunę,

Ogień po całym domu rozsiewając.

W porządku epickiej narracji Eneidy scena ta jest figuratywną zapowiedzią tego, co nastąpi, czyli wojny Eneasza z lokalnym konkurentem do ręki Lawinii, Turnusem, oraz ostatecznego zwycięstwa Trojańczyka, które stanie się początkiem chwalebnej historii Rzymu. Natomiast w porządku poetyckim wersy o płonących włosach stanowią jeden $\mathrm{z}$ tych fragmentów poematu (jakże wyrazistych na tle uroczystej narracji oraz solennych przemów 
bohaterów), w których dokonuje się uobecnienie mityczno-legendarnej przeszłości" ${ }^{11}$ W podobny sposób oddziałują końcowe wersy u Różyckiego: długo wyczekiwana Lawinia, jedna i zwielokrotniona, mityczno-poetycka i realistyczna, staje się wreszcie obecna $^{12}$. Jakżeby miało być inaczej, skoro wiersz, jak zapowiada tytul, jest o niej?

Wraz z wizją płonących włosów Lawinii do intertekstualnej przestrzeni wiersza Różyckiego wchodzą też dwa odblaski tej wizji w Eneidzie. Pierwszym jest pochodzący z Księgi XII wspaniały opis Lawinii rozpalonej miłością:

Z twarzą płonącą, a zalaną łzami:

Ogień owionął ją, ciemnym rumieńcem

Ogarnął lica gorące. Jak wtedy,

Kiedy ktoś eburn indyjski nasycił

Krwawą purpurą, albo jak się białe

Lilie czerwienią zmieszane z różami,

Taką pałała barwą twarz dziewczyny,

A w nim się miłość pali. [...]

[E XII 95]

(Łzy Lawinii, warto odnotować, były reakcją na twarde słowa matki: „Przenigdy, niewolna, / Nie ujrzę jako zięcia Eneasza” [E XII 93-94]). Wczesną antecedencją tej sceny wydają się słowa:

Uobecniający potencjał tego fragmentu ma źródło w zastosowaniu wielu środków: od skrócenia dystansu narracyjnego na skutek użycia praesens historicum poprzez dokładne unaocznienie wszystkich szczegółów (co, jak pokazał Erich Auerbach [2004: 32], jest typową techniką eposu homeryckiego) aż po oddziaływanie poetyckiej nadorganizacji brzmieniowej (o którą zadbał polski tłumacz: „Z trzaskiem gorzeje”, „w żółtą łunę” etc.) oraz rytmicznych nawrotów wiersza. Hans Urlich Gumbrecht [2016: 46] przekonująco objaśnil, jak rytm poetycki „przerywa i zamraża nieodwracalny przepływ codziennego czasu” i w ten sposób wytwarza „okno”, przez które „momenty i rzeczy z przeszłości [ ... ] mogą stać się dla nas obecne i jakby «namacalne»".

Tym razem uobecnienie dokonuje się przede wszystkim dzięki wzmiance o „ognistych włosach”, która czytana bez intertekstualnych odniesień wydaje się jakimś nie do końca zrozumiałym estetycznym ornamentem i działa trochę jak opisane przez Rolanda Barthes'a [2012] niefunkcjonalne szczególy wytwarzające „l'effet de réel”. 
"Już rumieniły się wody" [E vil 32], od których rozpoczyna się fragment przedstawiający, jak nawy Eneasza zbliżają się do ujścia Tybru. Wszystkie te trzy obrazy odbijają się w sobie: rumieniec na nieruchomym morzu u „brzegów lawińskich”, miłośnie rozpłomieniona twarz Lawinii, włosy zajęte świętym ogniem. Płomienisty motyw spaja ze sobą przepowiednię przyszłości, miłość oraz wytęsknione Lavinia litora - i w takiej troistej postaci przenika do wiersza Różyckiego.

W regresywnej lekturze Lawinii chodzi nie tyle o śledzenie historii uchodźców - ta jest już znana, nawet jeśli opowiedziana została w sposób dalece niedoskonały - ile o wychwycenie takich właśnie odblasków. Zabarwiają one tęsknotą, nadzieją, czułością, a niekiedy i żarem słowa już wcześniej słyszane, np. tę natarczywą litanię próśb: „O trochę miejsca dla bogów ojczystych, / O brzeg bezpieczny, o to, co jest wszystkim / Dostępne: wodę i powietrze $[\ldots]$ ”. W narracji reportażowej słowa te odzywały się dalekim echem, zniekształcone, nieprzychylnie zinterpretowane. Teraz dopiero można je usłyszeć wyraźnie jako wołanie o azyl, o najdosłowniej pojęte schronienie. Podobnie „suche placki” gryzione przez mężczyznę w obozie dla uchodźców stają się tym, czym były u Wergiliusza - znakiem spajającym cierpienie i nadzieję: „To właśnie głód ów był, owa ostatnia / Bieda, co naszą długą poniewierkę / Miała zakończyć [...]” [E VII 170]. Trzeba również odszukać pewien przejmujący fragment z Księgi I, by znaleźć się bardzo blisko kogoś, komu udało się ujść rozszalałym morskim falom: „Z jakąż radością, stęsknione za ziemią / Stopy trojańskie dotykają brzegu, / Na piasku kładą się schłostane, solą / Ociekające ciała. [...]” [E I 236-239].

Okazuje się, że czytany uważnie epos sprzed dwóch tysięcy lat - mimo oczywistych rozbieżności fabularnych - trafnie i precyzyjnie ujmuje to wszystko, co współczesny telewizyjny reportaż, będący przecież z definicji formą dokumentalną, w pośpiechu przemilcza lub, co gorsza, przedstawia w sposób okaleczony. Nie chodzi o „wszystko” w sensie kompletnego obrazu, ale o okruchy prawdy, które mają wartość materialnego świadectwa życia i śmierci konkretnych ludzi (bohaterowie Lawinii, choć anonimowi i pozbawieni indywidualnych rysów, są kimś więcej niż tylko figu- 
rami uchodźców). Te okruchy prawdy przedostają się również do Lawinii. W wierszu Różyckiego znajduje się kilka miejsc, w których z niewyraźnego tła wyodrębniają się nieliczne detale, punktowo oświetlone słowa-rzeczy: „łódź”, „fala”, „piasek”, „żwir”, „druty”, „suche placki” ${ }^{\prime 3}$. Wszystkie one odnoszą się do materii przylegającej do ciał uchodźców (same ciała nie zostały przedstawione, tylko zamarkowane kategoriami ogólnymi: „uchodźcy”, „dzieci”, „ktoś”). Ta metonimiczna przyległość, a właściwie zastępstwo, wytwarza, jak to ujął holenderski historyk Eelco Runia [2010: 101, 102], „fistuły”, czyli przejścia czy otwory, przez które do poetyckiej fikcji przedostaje się rzeczywistośćc ${ }^{14}$. W Lawinii przejścia te prowadzą ponadto do literackich hipotekstów, np. „suche placki” wywołują scenę z wygłodniałymi Trojanami ucztującymi pod drzewem, a „piasek” i „żwir” - przejmujący obraz ociekających solą, umęczonych ciał na plaży. W ten sposób uobecniana rzeczywistość rozszerza się.

Niezwykła moc intertekstualnych odniesień Lawinii polega również na tym, że uzupełniają one „obiektywnie” zrelacjonowaną historię uchodźców o obrazy i sceny przedstawione z ich perspektywy. Wspominałam wcześniej, że kamera telewizyjna ustawia się zawsze po „naszej” stronie - łódź uchodźców obserwowana jest z lądu, z „brzegów lawińskich”, które nie są tłem, lecz punktem widzenia, i w ogóle nie są przedstawione w reportażu. Tymczasem u Wergiliusza Lavinia litora widziane są od strony morza, oczami obcych przybyszów, i uzyskują konkretny kształt:

Auerbach [2004: 37] w Bliźnie Odyseusza pokazał, że w epice biblijnej takie punktowe oświetlenie detali, podczas gdy wszystko inne pozostaje w cieniu, w połączeniu z ubogą w zdarzenia fabułą i przemilczaniem lub bardzo oszczędnym przytaczaniem wypowiedzi bohaterów, sprzyja wytworzeniu dodatkowych planów semantycznych, które domagają się interpretacji. Wyjaśniałoby to, dlaczego Lawinia wykazuje podatność na odczytania paraboliczne. Podejrzewam jednak, że podstawowa funkcja takiego punktowego oświetlenia jest $\mathrm{w}$ tym wypadku inna.

O metonimii pisal Eelco Runia [2010: 76], że „oznacza «obecność w nieobecności» nie w takim sensie, że ukazuje coś, czego tam nie ma, ale w takim, że choć nieobecna (a przynajmniej rażąco niewidoczna) rzecz, której tam nie widać, jednak tam jest obecna”. W Lawinii w ten sposób niewidoczne (lub słabo widoczne) są właśnie ciała uchodźców. 


\section{[...] Z nieruchomym}

Morzem zmagają się wiosła, gdy z nawy

Eneasz widzi przed sobą ogromny

Bór: $\mathrm{z}$ jego głębi Tyber nurtem błogim

A rwącym, płowym od nadmiaru piasku,

Do morza wpada. Dokoła i w górze

Ptaki przeróżnej barwy, zagnieżdżone

Na brzegach Tybru i w jego korycie

Przestworze śpiewem czarowały, w lesie

Fruwając. Każe druhom zmienić drogę

I ku lądowi dzioby naw obrócić.

$\mathrm{Z}$ radością wplywa w ocienioną rzekę.

[E vil 35-46]

Obraz jest oczywiście konwencjonalny; las, śpiewające ptaki, rzeka, cień - pochodzą z ustalonego repertuaru locus amoenus. Idylliczne wymodelowanie pejzażu może jednak służyć czemuś więcej niż tylko panegirycznej retoryce rzymskiej epopei narodowej. Nie będzie chyba błędem, jeśli przyjmiemy, że idealne piękno „brzegów lawińskich” zostało narzucone spojrzeniem człowieka, który do tych brzegów gorąco tęskni, który pragnie widzieć w nich zapowiedź nowego domu. Podstawiając w miejsce Eneasza współczesnego uchodźcę, Lawinia podpowiada, jak widzi on dzisiejsze Lavinia litora.

Możliwe, że takie odczytanie Eneidy, z akcentem na tęsknotę i pragnienie, zawdzięcza Różycki współczesnemu tłumaczowi Wergiliusza - Kubiakowi, który swoją przedmowę do eposu zatytułował „Eneida”, tódeczka na morzu i opatrzył mottem z Czyśćca Dantego: „[... alza la vele / omai la navicella $[\ldots] ”(,[\ldots]$ napina żagle / łódeczka [...]"). Tytułową metaforę thumaczył Kubiak [1998: 7] następująco:

Kiedy się w Rzymie błądzi pośród murów i ogrodów między Awentynem, Koloseum, Lateranem i Termami Karakalli, można trafić niespodzianie - u szczytu wzgórza Celius - na mały plac, który nawet w tej pięknej dzielnicy jest przedziwną oazą piękna: Piazza della Navicella. Nazwa pochodzi stąd, że 
na środku placyku - w księżycu tak cichego, jakby był poza Rzymem, poza światem - stoi u wrót kościoła Santa Maria in Dominica wykuta w białym marmurze łódeczka, kopia dawnego wotum marynarzy cudzoziemskich. Pomyślałem sobie kiedyś, że ta skamieniała łódeczka jest jak Eneida, poemat o burzliwej wędrówce, cały przeniknięty pragnieniem spokoju, tyle razy wypowiadanym przez Eneasza słowami, których tonu, jeśli się go raz posłyszy, już nie można zapomnieć, jak w wierszach $\mathrm{z}$ księgi vi, 85-87 [...]:

Uciekających wybrzeży Italii

Oto dopadliśmy już! Tylko dotąd

Mogła nas ścigać trojańska niedola.

Domniemanie, że pomysł na Lawinię pochodzi z tego właśnie fragmentu eseju, wydaje mi się mało istotne, bo między Kubiakiem a Różyckim wyczuwam przede wszystkim gębokie pokrewieństwo. Znamienne, że tłumacz zwraca uwagę właśnie na ton Eneidy - jest to bliskie programowi Lawinii, podobnie jak technika rozszczepiania przestrzeni na "tutaj” i „niezupełnie tutaj” (navicella stoi w Rzymie, „brzegi lawińskie” okazują się ruchome w dosłownym sensie: ujście Tybru znajduje się dziś gdzie indziej niż w czasach starożytnych, „morze odeszło dosyć daleko” [Kubiak 1998: 31]). Obaj autorzy dzielą także umiejętność skracania dystansu między rzeczywistością i fikcją, teraźniejszością i historią. O miasteczku Ostia Antica, miejscu lądowania Eneasza, pisze Kubiak: „[... ] nie czuje się tu otchłani czasu”, i wyobraża sobie, jak gdzieś w pobliżu historyczni przybysze z Azji Mniejszej „ułożyli się do pierwszego snu na gołej ziemi” [Kubiak 1998: 31-32].

Esej o Eneidzie ma jeszcze jeden punkt styczny z wierszem Różyckiego: postać dziecka. Kiedy Kubiak [1998: 32-33] zastanawia się nad „olbrzymią, nieprzezwyciężalną zwykłością” Rzymu, który jest „jak chleb, chleb olbrzymi”, pyta nagle: „Po to więc Eneasz wędrowal, żeby teraz ten mały chłopiec z piłką w rękach biegł po trotuarze ulicy?” - i zaraz sobie odpowiada: „Tak, chyba właśnie po to". Jeśli potraktować te słowa jako kolejny hipotekst Lawinii, to nabierają one znamion narracji kontrfaktycznej: tak mogłoby być, 
gdyby morska „odyseja” skończyła się szczęśliwie. Znów jednak nie chodzi o antytezę, lecz o głęboką korespondencję. W Lawinii dziecięca podróż przebiega torem alternatywnym do głównej linii fabularnej. O ile dorośli uchodźcy są niekiedy w stanie dotrzeć do „żwirowej plaży”, a potem do miejsca „za drutami, przy węźle autostrad", o tyle dzieci (nigdzie nie jest wprost powiedziane, że chodzi o martwe ciała) pokonują trasę zawiłą, prawie niemożliwą do przebycia: „Avalon, Itaka, Lampedusa”. Wewnętrzny dialog Kubiaka jest być może najintymniejszym ustępem eseju o Eneidzie, natomiast trzy wersy Lawinii opowiadające o owej fantastycznej „odysei” wydają się najbardziej prawdopodobnym miejscem, w którym można by obsadzić formalnie nieobecne „ja” samego poety ${ }^{15}$.

Wersy te otwierają bowiem prześwit na dalszą twórczość Różyckiego. Ktoś, kto czytając Litery w założonym przez poetę porządku, po Lawinii (nr 18) natrafi na Prąd wstępujący (nr 29) i Grotę nimf (nr 95), może powiązać opowiadane w tych ostatnich przygody „ciała wyniesionego na wysokie morze” z podróżą dzieci zmytych z łodzi przez falę w Zatoce Imienia Syreny. Czytane bez tego kon-

Uprzedzając argumentację, która zaraz nastąpi, a także powtarzając za Różyckim manewr zboczenia z głównej trasy w kierunku wyznaczonym przez swobodną grę wyobraźni, chciałabym - na tyle niezobowiązująco, na ile to możliwe - powiązać to obsadzenie „ja” poety w roli dziecięcego ciała zabranego w „długą odyseję" i złożonego „na piasku Avalon, Itaki, Lampedusy” z pewnym dziełem sztuki wizualnej. W 2016 roku Ai Weiwei zainscenizował na plaży w Lesbos fotograficzny autoportret, w którym upozował się według reporterskiego zdjęcia przedstawiającego ciało uchodźcy z Syrii, trzyletniego Alana Kurdiego (na zdjęciu dziecko leży na linii przybrzeżnych fal, twarzą do piasku; na bliższym planie widać jasnobrązowe podeszwy malutkich bucików). Widzę tu i podobieństwo, i kilka różnic. Gest poety nie polega na naśladowaniu rzeczywistości (lub jej dokumentalnych reprezentacji, takich jak reporterska fotografia), obsadzenie nie jest dosłowne, czyli formalnie pierwszoosobowe, niemniej ujęcie uchodźczej „odysei” w ramy tej samej poetyki, którą Różycki uruchamia w kontekstach autobiograficznych, odczytuję jako znak utożsamienia. Rysem wspólnym dzieł Różyckiego i Ai Weiweia są też przesunięcia przestrzenne (chłopczyk z fotografii nie został znaleziony na Lesbos, lecz na wybrzeżu tureckim, w pobliżu portu Bodrum), domyślam się jednak, że motywacje obu artystów nie były w tym wypadku zbieżne: przeniesienie sceny na Lesbos miało zapewne zwrócić uwagę publiczności na szerszy kontekst tragedii (na greckiej wyspie znajduje się obóz dla uchodźców). 
tekstu, wiersze te w ogóle takich sensów nie uruchamiają. Nie ulega natomiast wątpliwości ich powiązanie z imaginarium i prywatną mitologią poety. Marynistyczna fiksacja Różyckiego ma fundamenty autobiograficzne, wywodzi się z lektur dzieciństwa oraz z anegdot dziadka, który przed wojną miał wieść barwne życie jako marynarz i awanturnik. „Dzieci, one uwielbiają kolorowe historie, pełne przygód i dziwności. Fantazję i fikcję" [Różycki 2013: 135] - pisał poeta o tych opowieściach. Egzotyczno-podróżnicza topika stanowi osnowę tomu Kolonie (2006) i uaktywnia się w innych utworach poety, w tym we wspomnianych wierszach z Liter. Stałym motywem jest tu wyspa, z reguły urojona lub iluzoryczna (w Pradzie wstępujacym pomylona z wielorybem: „[... ] lecz to tylko płetwal wynurza się na moment, / żeby się pożegnać przymknięciem powieki” [Różycki 2016: 40]), zawsze objęta jakimś rodzajem czułej ironii. W obrazach południowych mórz charakterystyczne jest też przemieszanie śródziemnomorskiej mitologii z „pióropuszami pieprzowców, migdałowców” oraz innymi atrybutami egzotyki. W Grocie nimf dryfującemu ciału towarzyszą całe zastępy morskich istot:

Towarzysze i pasożytnicze porosty,

klucze trytonów, nereidy o białych piersiach, eskadra syren. I mijane są atole,

Wyspy Szczęśliwe migają w pianie odboju,

Przylądek Dobrej Ułudy, Przylądek Strachu

i Wyspa Dantejska. [... ]

[Różycki 2016: 111]

Trudno odeprzeć wrażenie, że takie oniryczno-fantastyczne obrazy są jakoś pokrewne „długiej odysei” dziecięcych ciał w Lawinii, zwłaszcza że współtworzy je metaforyka utraty (widmowa wyspa w Prądzie wstępującym nazwana jest „witryną ubytków”), także utraty życia. Motyw ciała swobodnie unoszącego się na wodzie jest niejednoznaczny, bezwładność konotuje zarówno głęboki relaks, jak i śmierć (może dlatego samobójstwo na jachcie „kołyszącym się u wybrzeża Capri” zostało w Strefie komfortu uznane za najlepsze). Oba te sensy uaktywniają się w zapisie wspomnienia 
z plaży w Cap d’Agde w autobiograficznym fragmencie eseistycznej książki Tomi. Notatki z miejsca postoju:

Czarny wulkaniczny żwir, nagrzany przez słońce tak, że parzy. Pływają w słonej, bardzo słonej wodzie w zatoczce, która kiedyś była okiem wulkanu. Woda wyrzuca ich na powierzchnię, wszystko jest nierealne, tak nierealne, że niemal zasypia, kołysząc się w morzu. Ten moment zaśnięcia, utraty czujności w oku Polifema, czy nie był grzechem? [Różycki 2013: 219-220]

Kołysanie się na wodzie po raz kolejny wiąże morze z dzieciństwem („morze lubi dzieci” i vice versa), a także z poczuciem bezpieczeństwa - tyle że jest to bezpieczeństwo chwilowe, a nawet złudne oraz obciążone pewnym kosztem o niejasnym zabarwieniu moralnym. Nie jest więc tak, że poeta nie dostrzega ciemnego rewersu swoich prywatnych mitów i fantazmatów; zapewne można by o nich powiedzieć to, co sam autor Tomi odniósł do mitologii kulturowejże niosą „śmierć dla oglądającego i własny kres” [Różycki 2013: 42]. Mimo to Różycki uparcie pozostaje im wierny. W wierszu Wirus z Liter, zaczynającym się od słów: „Tu na piasku tylko dla ciebie zapisałem [...]", wspomnienie z wulkanicznej plaży staje się przedmiotem aktywnej, wytężonej pracy pamięci ocalającej od niebytu: „Pamiętać o szczegółach: widoku na góry, / odbitym pod powieką, kołysce dla ciała / w ciepłej jak dłoń zatoce. [...]” [Różycki 2016: 96].

Ćwiczenia pamięci mają też wymiar kultywowania dziecięcych marzeń, pielęgnowania naiwnej beztroski, by jednak móc sobie czasem pozwolić na „utratę czujności w oku Polifema” - i tu znajduję powrotny skrót do chłopca, który może biec z piłką dzięki trudom tułaczki Eneasza, oraz do „długiej odysei” dziecięcych ciał w Lawinii. Podróż, w którą morze zabiera uchodźców, jest syntezą trudu Eneasza i beztroski dziecka, lączy w sobie wolność „,ciała wyniesionego na wysokie morze" i śmierć w Zatoce Imienia Syreny. Zewnętrzny kontekst Lawinii - choć ta zewnętrzność jest umowna, bo twórczość Różyckiego stanowi w zasadzie jeden wielki tekst ${ }^{16}$ - aż z nadmiarem rach, z których, jak pisze, nie da się „wyciąć «wymyślonego prostokąta» tekstu, 
dostarcza przesłanek, by przypuszczać, że „ja” wiersza (gramatycznie nieobecne, ale stanowiące podmiotowy zwornik utworu) obejmuje podróż uchodźców czułym spojrzeniem. W trzeźwym oglądzie, takim, jaki oferuje progresywna narracja Lawinii (ujęta w ironiczny nawias), ich fantazje musiałyby spotkać się z naganą wszak przez takie mrzonki giną niewinne dzieci; komentator jawnie nieprzychylny powiedziałby zaś: to tylko mydlenie oczu, ci ludzie są wyrachowani, oni wiedzą, co robią. Empatyczna perspektywa regresywnego toku Lawinii wydobywa z tych rojeń i pragnień zupełnie co innego: wzruszającą naiwność, smutne piękno.

O kształcie uchodźczych fantazji informuje trasa „długiej odysei", która jest podróżą alternatywną względem tej rzeczywistej, odbywanej przepełnioną łodzią po Morzu Śródziemnym. Punkt docelowy to zawsze Wyspa - szczęśliwa jak Sycylia w Syrenie, dająca życie jak Avalon w cyklu arturiańskim, wytęskniona jak Itaka u Homera. Mitologiczny komponent, obejmujący i syrenę Ligheę, i Graala, i Penelopę, nadaje Wyspie wymiar metafizyczny, a zarazem baśniowy. Lampedusa, znajdująca się na końcu szeregu (lub na początku, skoro lektura podąża teraz wstecz), pełni w wyobraźni współczesnych uchodźców analogiczną funkcję: jest po prostu Wyspą. Przypomnę, że w optyce telewizyjnej destynacją uchodźców była Zatoka Imienia Syreny, powiązana zarówno z Lampedusą, jak i z Sycylią. Pisałam już o turystyczno-marketingowych konotacjach tej nazwy; dodam, że ironicznie potwierdza je fragment z Syreny Lampedusy, w którym jeden z bohaterów wyraża radość, że zatoczka powyżej Punta Izzo w Auguście, „najpiękniejsze miejsce na Sycylii”, nie została jeszcze odkryta „przez wycieczkowiczów” [Lampedusa 2005: 16] - no cóż, w świecie Lawinii najwyraźniej nie jest to już prawda (a ogłoszenia na internetowych portalach, zachęcające do odbywania podróży sulle tracce della Sirena, dowodzą, że nie jest to prawda również w świecie realnym). Zatoka na Sycylii/ Lampedusie pozostaje jednak nieskalana w oczach tych, którzy do niej tęsknią, tak jak bohaterowie Syreny tęsknili do miejsca, gdzie

zawsze, w każdym z 99 wierszy tomu, istotne będą odniesienia do pozostałych”. Z pewną ostrożnością można tę konstatację rozszerzyć na całą twórczość Różyckiego, łącznie z prozą fabularną i eseistyką. 
„morze ma barwy pawia, a zaraz naprzeciw, po drugiej stronie tych mieniących się fal, wznosi się Etna" [Lampedusa 2005: 16], i tak jak Eneasz oraz jego towarzysze tęsknili, nie znając ich jeszcze, do dających cień „brzegów lawińskich”; do tego grona dołącza też sam Różycki ze swoją „,iepłą jak dłoń zatoką," o której koniecznie trzeba pamiętać.

Jak więc rozumieć to, że Zatoka Imienia Syreny jest dzisiaj „mętna”? Z perspektywy pragnienia i tęsknoty można w niej zapewne dojrzeć „płowe od nadmiaru piasku” nurty Tybru. Może jednak trzeba przysunąć się trochę bliżej miejsc, w których lądują dzisiejsi uchodźcy, i przypomnieć sobie scenę odejścia syreny Lighei. Wzburzone fale widziane są z brzegu, ale patrzy nie chłodne oko kamery, a ktoś, kto tęskni i doznaje straty:

Burza zerwała się dwudziestego szóstego o świcie. Ze skały widzieliśmy, jak wiatr spieniał dalekie wody, a w pobliżu nas leniwe, ołowiane fale szeroko wezbrały. Szybko dopadł nas huragan, gwizdał nam w uszach, łamał wysuszone rozmaryny. Morze otworzyło się pod nami, już ośmieliła się podpłynąć pierwsza fala okryta bielą. „Addio, Sasà. Nie zapomnisz nigdy”. Grzbiet fali rozbił się o skałę, syrena rzuciła się w tęczowy rozprysk wody; nie widziałem, jak pogrąża się w toni; jakby się rozpłynęła w pianie morskiej. [Lampedusa 2005: 24]

Odejście Lighei nie było zupełnym końcem miłosnej historii przedstawionej w opowiadaniu Lampedusy; wolno mieć nadzieję, że historii tej nie zakończyła nawet śmierć profesora La Ciura. Syrena nie przestała przecież istnieć, a tylko „jakby się rozpłynęła w pianie morskiej”. Podobnie w Lawinii dokonujące się „dzisiaj” zatonięcie łodzi, choć jest momentem utraty (życia, złudzeń), nie kończy podróży napędzanej dziecięcą tęsknotą. Podróż ta wiedzie współczesnych uchodźców przez Zatokę Syreny - zmąconą przez burzowe fale, ale wypełnioną ukochanym Imieniem - do „brzegów lawińskich”, które znajdują się „tutaj” i „niezupełnie tutaj”: u ujścia Tybru, na Sycylii, na Lampedusie, a także - niech będzie wolno przypuścić - w Parco Virgiliano nad zatoką zwaną czasem, od imienia innej syreny, Zatoką Partenopejską. 


\section{Bibliografia}

Auerbach Erich (2004), Blizna Odyseusza, w: tegoż, Mimesis.

Rzeczywistość przedstawiona w literaturze Zachodu, przeł. i przedmową opatrzył Zbigniew Żabicki, przedmowa do drugiego wydania Michał Paweł Markowski, Prószyński i S-ka, Warszawa, s. 29-48.

Barthes Roland (2012), Efekt rzeczywistości, przeł. Michał Paweł Markowski, „Teksty Drugie”, nr 4, s. 119-126.

Curtius Ernst Robert (2009), Literatura europejska i łacińskie średniowiecze, przel. i oprac. Andrzej Borowski, Universitas, Kraków.

Czabanowska-Wróbel Anna (2019), Ekonomia „Liter”, w: Obroty liter. Szkice o twórczości Tomasza Różyckiego, red. Magdalena Rabizo-Birek, Anna Czabanowska-Wróbel, Universitas, Kraków, s. 311-332.

Genette Gérard (2014), Palimpsesty. Literatura drugiego stopnia, przeł. Tomasz Stróżyński i Aleksander Milecki, słowo/obraz terytoria, Gdańsk.

Gumbrecht Hans Urlich (2016), Jak podchodzić do „poezji jako rodzaju uwagi”?, przeł. Joanna Krajewska, „Forum Poetyki”, nr 3 (zima), s. $42-53$.

Kubiak Zygmunt (1998), „Eneida”, tódeczka na morzu, w: Wergiliusz [właśc. Publiusz Wergiliusz Maro], Eneida, przeł. i oprac. Zygmunt Kubiak, Świat Książki, Warszawa, s. 7-41.

Lampedusa Giuseppe Tomasi di (2005), Syrena, przeł. Michał Bristiger, Jadwiga Dąbrowska, „Zeszyty Literackie”, nr 3/91, s. 5-24.

Różycki Tomasz (2013), Tomi. Notatki z miejsca postoju, Fundacja Zeszytów Literackich, Warszawa.

Różycki Tomasz (2016), Litery, a5, Kraków.

Różycki Tomasz (2020), Kapitan X, as, Kraków.

Runia Eelco (2010), Obecność, przeł. Elżbieta Wilczyńska, w: Teoria wiedzy o przeszłości na tle wspótczesnej humanistyki, red. Ewa Domańska, Wydawnictwo Poznańskie, Poznań, s. 75-123

Stanisz Marek (2019), Ciemne metafory Różyckiego, w: Obroty liter. Szkice o twórczości Tomasza Różyckiego, red. Magdalena Rabizo-Birek, Anna Czabanowska-Wróbel, Universitas, Kraków, s. 143-159.

Wergiliusz [właśc. Publiusz Wergiliusz Maro] (1998), Eneida, przeł. i oprac. Zygmunt Kubiak, Świat Książki, Warszawa. 
Małgorzata Gorczyńska

„In the Siren Gulf”: Lawinia and Strefa komfortu by Tomasz Różycki

An expression used in the title of my paper refers to several places in contemporary and ancient Italy: the Gulf of Naples, the shores of Lampedusa and Sicily, and the mouth of the Tiber River. These places form the background of the tragedy of African and Middle East refugees shown in poems by Tomasz Różycki: Lawinia (Lavinia) from the collection Litery (Letter by Letter, 2016) and Strefa komfortu (Comfort Zone) from the newest poetry book Kapitan X (Captain X, 2020). My detailed analysis of the two texts is an attempt to describe their formal and semantic complexity, especially their unique tone that mixes sharp irony with tender compassion.

Keywords: Tomasz Różycki; Publius Vergilius Maro; tone; ironic imitation; empathy; refugees.

Małgorzata Gorczyńska - adiunkt w Instytucie Filologii Polskiej Uniwersytetu Wrocławskiego, prowadzi zajęcia z poetyki i twórczego pisania poezji. Stypendystka Czeskiej Akademii Nauk, autorka monografii Miejsca Leśmiana. Topika recepcji krytycznoliterackiej (2011), publikowała w takich czasopismach, jak „Pamiętnik Literacki” czy „Česká literatura”. Zajmuje się twórczością Bolesława Leśmiana, Tomasza Różyckiego i Bohuslava Reynka. Adres e-mail: malgorzata.gorczynska@uwr.edu.pl. 
